BIOMEDICAL AND BIOSOCIAL ANTHROPOLOGY
Official Journal of the International Academy
of Integrative Anthropology
journal homepage: http://bba-journal.com

\title{
Expediency of using a comprehensive approach in the identification of missing persons
}

\author{
Voichenko V. V. ${ }^{1}$, Roshchin G. G. ${ }^{2}$, Dyadyk O. O. ${ }^{2}$, Irkin I. V. ${ }^{2}$, Petrochak O. Yu. ${ }^{2}$, Kostenko E. Ya. ${ }^{3}$, \\ Vyun V. V. ${ }^{1}$, Zubko M. D. ${ }^{4}$ \\ ${ }_{1}^{1} \mathrm{PI}$ "Dnipropetrovsk Regional Clinical Bureau of Forensic Medical Examination" DRSA, Dnipro, Ukraine \\ ${ }^{2}$ P. L. Shupyk National Medical Academy of Postgraduate Education, Kyiv, Ukraine \\ ${ }^{3}$ Uzhhorod National University of the Ministry of Education and Science of Ukraine, Uzhhorod, Ukraine \\ ${ }^{4}$ SHEI "Zaporizhia State Medical University", Zaporizhia, Ukraine
}

\section{ARTICLE INFO}

Received: 09 September, 2019

Accepted: 14 October, 2019

UDC: $61: 02-12 / 1057-3$

CORRESPONDING AUTHOR

e-mail: dneprsme@ukr.net Voichenko V. V.

\begin{abstract}
The identification of missing persons in armed conflict and with mass casualties in emergencies has its own characteristics and requires an integrated approach to increase accuracy and objectivity. The aim of the study: justification of the appropriateness of an integrated approach in identifying persons missing in an armed conflict with mass casualties. In the work, archival materials of forensic medical examinations of the commemorative institution "Dnipropetrovsk Regional Bureau of Forensic Medical Examination" were used regarding those who died during the armed conflict with mass casualties in eastern Ukraine during 2014-2019. Research methods: anthropometric, morphometric, photographic, radiological, forensic methods, computer simulation method, molecular genetic, statistic. The article sets out the domestic experience of increasing the objectivity and accuracy of identifying missing persons and determining the characteristics of bodily injuries and traumatic factors through an integrated approach using anthropometric, morphometric, photographic, radiological, molecular genetics and medical and criminalistics methods and in situations of armed conflict with mass casualties. However, the presence of only a modern morgue and the latest equipment in the laboratory department of the forensic medical examination bureau is not a guarantee of a successful examination to identify the deceased. As the experience of different countries in the case of mass natural and man-made disasters shows - the key element is the correct and consistent organization of research. The experience of conducting identification studies in Ukraine of missing persons in an armed conflict with mass casualties of people indicates the appropriateness of applying an integrated approach that improves the objectivity and accuracy of the study. Keywords: identification of persons, missing persons, bodily injuries, traumatic factors of action, integrated approach.
\end{abstract}

\section{Introduction}

In many countries around the world, including Ukraine, the identification of the bodies of the dead remains an urgent problem due to cases of local military conflicts [24], mass catastrophes and natural disasters [25], as well as an increase in cases of unorganized migration.

Identification of the remains of missing persons includes complex scientific, technical, legal, ethnic and cultural issues. This is a huge layer of problems that has emerged in recent years and is increasingly spreading against the background of other pressing problems of today's society, and which all of us together professionals in various fields will have to solve more than one year, and perhaps more than a decade. Accordingly, this leads to an increase in the number of examinations to identify the person, as well as the need to develop new scientific and methodological approaches to solving this problem. Given the presence in the literature of systemic nature of identification tasks and ways to solve them, regardless of the causes that led to the mass death of people [1, 29], today we have our own domestic experience in organizing work on identifying missing persons and determining the characteristics of the body injuries and traumatic factors $[6,17,26]$, which includes effective approaches to odontological status [9-11], burnt bone remains [7, 8], 
dermatoglyphic parameters of the palms [18-20] and others.

The process of identification is complex and multistage, and originates from the place of discovery of the remains of the deceased. And if the detection of remains on the earth's surface does not cause significant difficulties in the first stage, the detection of both single and mass burials is a more complex process that requires the involvement of forensic anthropologists and archaeologists [28]. At the next stage, after the evacuation of all the remains of the body, it is necessary to establish which parts of the body, the bones of the corpse are present; begins the process of gender, physique, height, ethnicity and race, identification of intravital and postmortem injuries [25], uses different types of medical imaging of soft tissues and bones [28], if possible and necessary, an autopsy with subsequent removal of materials for forensic laboratory.

It should be noted that the identification of missing persons in armed conflict and with mass casualties in emergencies has its own characteristics and to improve accuracy and objectivity requires a comprehensive approach with the appropriate amount of anthropometric, morphometric, photographic, radiological, molecular genetics and medical-criminalistics research methods.

The aim of the study was to substantiate the feasibility of a comprehensive approach to the identification of missing persons in armed conflict and with mass casualties.

\section{Materials and methods}

1509 "Expert conclusions" from the archive of PI "Dnipropetrovsk Regional Clinical Bureau of Forensic Medical Examination" were used in the work, including archival materials of the department of forensic examination of corpses, departments of forensic criminology, forensic histology, forensic immunology, forensic cytology, regarding the identification of 1509 victims of the armed conflict in eastern Ukraine during 2014-2019. The research results were processed by standard methods of variation statistics.

The following research methods were used to identify people who died in the armed conflict: anthropometric, morphometric, photographic, radiological, forensic methods, computer modeling, molecular genetics, statistical.

\section{Results}

Significant damage to the tissues and organs of corpses, which impedes their identification, makes the identification of persons killed in armed conflict or as a result of emergencies a daunting task. Our own experience has shown that during hostilities due to artillery shelling from jets, a plane or helicopter crash, or when the body has been in unfavorable conditions on the battlefield for a long time, identification is much more difficult. Under these conditions, the bodies of the dead are most often mutilated beyond recognition or burned to the ground (Fig. 1), however, hundreds of unidentified bodies and their fragments need to be identified.

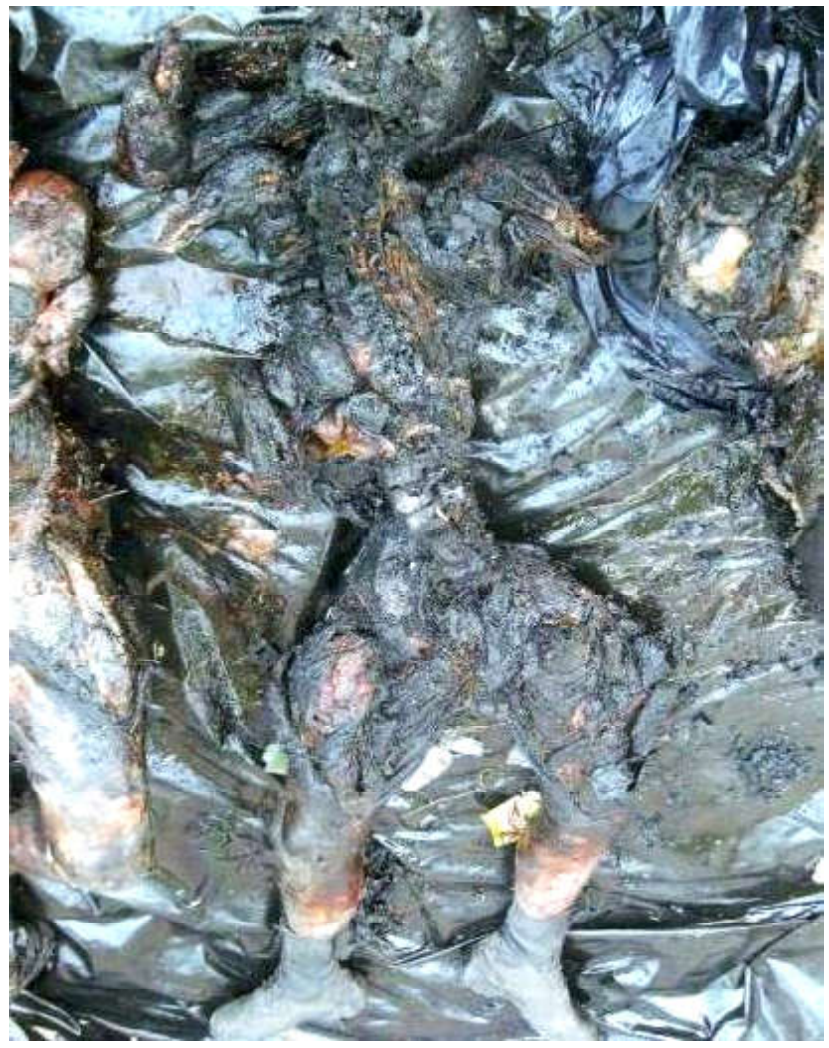

Fig. 1. Destructive changes in tissues and organs of corpses that prevent the identification of a person (photo from the archive of PI "Dnipropetrovsk Regional Clinical Bureau of Forensic Medical Examination").

Table 1. The number of forensic examinations conducted in PI "Dnipropetrovsk Regional Clinical Bureau of Forensic Medical Examination", in order to identify persons who died in the armed conflict in eastern Ukraine during 2014-2019.

\begin{tabular}{|c|c|}
\hline Year & Number of forensic examinations \\
\hline 2014 & 386 \\
\hline 2015 & 678 \\
\hline 2016 & 200 \\
\hline 2017 & 153 \\
\hline 2018 & 69 \\
\hline 2019 & 23 \\
\hline Total & 1509 \\
\hline
\end{tabular}

Since the beginning of the armed conflict in eastern Ukraine, the Dnipropetrovsk Regional Bureau of Forensic Medical Examination has conducted 1,509 forensic medical examinations of fallen servicemen of the Armed Forces of Ukraine, law enforcement agencies, and soldiers of volunteer formations in order to identify them (Table 1).

During the examinations, 1,399 victims were identified and handed over to relatives for burial. It should be noted that 947 people were identified by visual identification. At the same time, valuable information material for identification was: 1) identification of anatomical features (presence of a trepanation hole, exostoses, antetorta - 
internal rotation of the thigh, signs of gigantism, etc.); 2) research of clothes, documents, jewelry, various items; 3) research of tattoos, which carry significant information loads and were valuable in identification.

The use of DNA analysis ensures the reliability of identification of a person $99,999 \ldots . . \%$ by confirming or excluding his identity with relatives and is highly informative compared to other traditional identification forensic methods [15, 27]. The principles of identification of a person who has left biological traces, according to DNA research, are well known and widely used. However, among the 43 European countries, the CODIS system of molecular genetic test systems is used in 22 countries, 12 countries use their diagnostic panel systems, and for 9 countries, including Ukraine, only some forensic offices are available, including - in the Dnipropetrovsk regional bureau. According to the results of molecular genetic examinations, we identified 359 people. However, it should be noted that DNA analysis does not guarantee the maximum identification of a missing or unidentified person, as there may be an expert error or significant destruction of biological material found in traces on physical evidence with DNA degradation. Thus, in our study, due to DNA degradation, the biological objects of 8 people were not identifiable.

It is known that the identification of a person by dental status in world practice is one of the effective methods [911]. However, out of 1509 deaths, only 8 people were identified by dental status.

According to other types of identification: dactyloscopic examination, portrait - osteological identification of a person by the method of photocombination of the corpse skull and in vivo photograph of the missing person, X-ray examination (comparison of the radiograph of the examined part of the corpse with the lifetime radiograph of the same section of the human skeleton) was identified - 85 people.

Unfortunately, 102 remains of the dead remained unidentified due to the lack of comparable biological samples from the relatives of the dead.

\section{Discussion}

According to the definition of INTERPOL Disaster Victim Identification [16], personal identification is the identification of a person by a set of all the properties that distinguish him from other people. Therefore, as today's practice shows, the most effective and objective is a comprehensive approach to identifying the bodies of persons killed in armed conflict and missing persons, which should include the following basic methods and techniques [5, 15, 18]: 1 ) fixation of facial features; 2) dactyloscopic examination; 3) detection of anatomical features (congenital anomalies of the skeletal system and internal organs, trauma (trepanation), gigantism and dwarfism, etc.; 4) recognition of pathological changes; 5) research of special signs scars, ulcers, congenital spots, deformations of parts of the face, prostheses, defects of the musculoskeletal system, etc.; 6) study of the structure of the auricle, which, in terms of information, corresponds to dactyloscopic studies; 7) research of various subjects: clothes, documents, jewelry; 8) research of the person on bone remains which remains even after action of high temperature can be sufficient for diagnosis of lifelong fractures, malformations, diseases, etc.; 9) carrying out portrait-osteological identification [17], which includes the method of photo-combining the skull of a corpse and a lifelong photograph of a missing person.

The dermatoglyphic method along with the descriptive method of research is the most widespread and most often applied in cases of need of identification of persons. This method has become especially popular as a result of its cheapness and simplicity, and at the same time considerable informativeness, allowing not only to identify a particular person, but also his regional affiliation [13, 23]. Thus, for the male population of Ukraine it is established that such indicators as Cummins index, size of palm angles, localization and saturation of the palm with patterns, length of c-t segment and presence/absence of additional axial triradii have high value for regional differentiation [14].

Thus, the inappropriate use of only one specific method of research is indicated by the authors who analyze the work of forensic services in identifying the dead after the earthquake and tsunami in 2004 in Southeast Asia [25]. As a result of the lack of basic methods of storing corpses and mass destruction, there was a need to identify a large number of people. In Thailand, one of the main methods of identifying the dead was dermatoglyphic and odontological methods. In Sri Lanka - photographic and dermatoglyphic method as well. At the same time - DNA analysis was practically not used.

Extremely important identification value is the study of the chemical composition of the factors accompanying the shot, as part of these objects, using laboratory methods both traditional - contact-diffusion method (color imprint method), Vladimir's physical test, Aidlin's chemical test and microscopic method [2], and the newest, which have high technological capabilities, in particular - X-ray fluorescence spectral analysis and scanning electron microscopy. It is their use that provides the possibility of partial species identification of firearms according to the peculiarities of the shape of the cut of the channel of its barrel; the ability to establish the position of the muzzle relative to the surface of the skin when firing; determine the sequence of shots; to determine the elemental composition of shell and nonshell metals, fired and unfired bullets for their identification $[3,4,12,22]$.

Finding the right, unified algorithm for identifying the dead in different situations - from natural to man-made disasters, the discovery of mass graves, etc., has long been a task of many organizations, including INTERPOL, the International Committee of the Red Cross, the Academy of Forensic Medicine and Science and forensic 
associations. However, experience shows that often existing protocols and approaches to solving these problems do not work at full capacity, forcing researchers to further seek and improve existing algorithms and create new ones.

\section{Conclusions}

Analysis of archival material of the PI "Dnipropetrovsk Regional Clinical Bureau of Forensic Medical Examination",

\section{References}

[1] Ardashkin, A. P., \& Yudina, N. G. (2005). On the methodology of organizing forensic medical work on personal identification in emergency situations with mass casualties. Forensic-medical examination, (1), 32-25.

[2] Bobkov, P., Lebed, M., Perebetiuk, A., \& Gunas, V. (2019). Forensic characteristics of damages to artificial leather caused by gunshots from a "Fort-17 R" pistol. Bukovinian Medical Herald, 23(2(90)), 51-56. http://dx.doi.org/10.24061/24130737.XXIII.2.90.2019.33

[3] Chykman, Ya. (2019). Analysis of chemical elements composition on the fire arms surface for identification of shots sequence. Folia Societatis Medicinae Legalis Slovacae. Bratislava, 9(1), 53-56.

[4] Chykman, Ya. V. (2017). Establishing the type of threads of the barrel of the weapon for its partial group identification by morphological features of the belt rubbing around the damage to clothing. Forensic-medical examination, (2), 66-69.

[5] Filipchuk, O. V., \& Gurov, O. M. (2013). Forensic criminology. Kharkiv Publishing House: "Disa Plus".

[6] Gerasimenko, O. I., \& Gerasimenko, K. O. (2018). Experience of forensic medical service in identifying persons in emergency situations with mass deaths. Forensic-medical examination, (1), 50-53.

[7] Golubovich, L. L., Zubko, M. D., Golubovich, A. L., \& Golubovich, P. L. (2018). Determination of body length (height) in the identification of a deceased person by burnt bone remains. Forensic-medical examination, (2), 57-61.

[8] Golubovich, L. L., Zubko, M. D., Golubovich, A. L., \& Golubovich, P. L. (2018). The need to consider changes in bone tissue under the influence of high temperature in the identification of a person by burnt bone remains. Forensic-medical examination, (2), 53-57.

[9] Goncharuk-Khomyn, M. (2017). Modification of Dental Age Estimation Technique among Children from Transcarpathian Region. Journal of International Dental and Medical Research, 10(3), 851-855.

[10] Goncharuk-Khomyn, M. Y. (2017). Review of the effectiveness of the use of forensic dental methods to determine the age of children and adolescents. Clinical dentistry, (4), 58-65.

[11] Goncharuk-Khomyn, M. Y., Stetsik, M. O., Stetsik, A. O., Krichfalushiy, S. I., Velykodna, M. V., \& Boychuk, M. M. (2017). Analysis of approaches to expert assessment of changes in dental status: forensic and methodological aspects. Young scientist, (12), 52-55.

[12] Grynchyshyna, A. (2019). Forensic medical characteristic of chemical elements detected by $\mathrm{x}$-ray fluorescent spectral analysis on the surface of non-shot and shot elastic bullets to shock traumatic action patrons "AE 9" and " TEREN-3 FP". Folia Societatis Medicinae Legalis Slovacae. Bratislava, 9(1), 57-61.

[13] Gunas, V. I., Mishalov, V. D., Serebrennikova, O. A., \& Klimas, L. A. (2018). General phenotypological picture of the finger including materials of the Department of Forensic Medical Examination of Corpses, Departments of Forensic Criminology, Forensic Histology, Forensic Immunology, Forensic Cytology, regarding the identification of 1509 dead persons, whose bodies were distorted by traumatic factors or disappeared in an armed conflict, indicates the effectiveness of a comprehensive approach that improves the objectivity and accuracy of the study.

dermatoglyphics of Ukrainian men: the contribution of individual regions. Reports of Morphology, 24(4), 41-46. https://doi.org/ 10.31393/morphology-journal-2018-24(4)-06

[14] Gunas, V. I., Mishalov, V. D., Serebrennikova, O. A., Klimas, L. A., \& Shayuk, A. V. (2018). Palmar dermatoglyphics of modern Ukrainians: regional trends. Biomedical and biosocial anthropology, (31), 11-17. https://doi.org/10.31393/bba312018-02

[15] Imaizumi, K., Taniguchi, K., \& Ogawa, Y. (2014). DNA survival and physical and histological properties of heat-induced alterations in burnt bones. Int $J$ Legal Med., (128), 439-446. https://doi.org/10.1007/s00414-014-0988-y

[16] INTERPOL (2008). Disaster Victim Identification. http: // www.interpol.int/Public/DisasterVictim/default. asp

[17] Kovalenko, M. Y. (2017). Possibility of preliminary identification (assumption identification) of a person by anthropometric features due to the impossibility of recognizing the face and other individual features of the person's appearance on video and photo images. Forensic-medical examination, (1), 8585.

[18] Kozan, N. (2017). Neural networks and perspective of their use in forensic medicine. Forensic-medical examination, (1), 88-91.

[19] Kozan, N. M. (2017). Forensic identification of the ethnoterritorial affiliation of an unknown person by dermatoglyphic parameters of the palms using discriminant analysis. Bulletin of Vinnytsia National Medical University, 1(21). 252-255.

[20] Kozan, N. M. (2017). The connection the dermatoglyphic of fingers and human's growth. Forensic-medical examination, (2), 23-26.

[21] Mihaylenko, O. V., \& Chykman, Ya. V. (2017). Ability to establish the position of the muzzle cut relative to the skin surface using X-ray fluorescence spectral analysis by metal distribution. Biomedical and biosocial anthropology, (29), 21923.

[22] Mihaylenko, O. V., \& Chykman, Ya. V. (2018). Detection of metal particles from a bullet casing for partial species identification of firearms using X-ray fluorescence spectral analysis. Bulletin of Vinnytsia National Medical University, 22(1), 39-45.

[23] Mishalov, V. D., \& Gunas, V. I. (2018). Discriminating models of dermatoglyphic priority of practically healthy men to southern or other administrative-territorial regions of Ukraine. Forensicmedical examination, (1), 17-21.

[24] Mishalov, V. D., Petroshak, O. Y., Hoholyeva, T. V., Gurina, O. O., \& Gunas, V. I. (2019). Forensic assessment of gunshot injuries in Maidan Nezalezhnosti protesters. World of medicine and biology, 69(3), 118-122. doi: 10.26724/2079-8334-20193-69-118-122.

[25] Morgan, O. W., Sribanditmongkol, P., Perera, C., Sulasmi, Y., Van Alphen, D., \& Sondorp, E. (2006). Mass fatality management following the South Asian tsunami disaster: case 
studies in Thailand, Indonesia, and Sri Lanka. PLoS medicine, 3(6), e195. https://doi.org/10.1371/journal.pmed.0030195

[26] Morgun, A. O., Khyzhnyak, V. V., Morgun, O. O., Malyhina, O. I., Voitov, Y. O., \& Pasuga, O. I. (2018). Ways to optimize the work of forensic experts in the face of mass deaths. Forensicmedical examination, (1), 38-45.

[27] Tsuchimochi, T., Iwasa, M., \& Maeno, Y. (2017) Chelating resinbased extraction of DNA from dental pulp and sex determination from incinerated teeth with Y-chromosomal alphoid repeat and short tandem repeats. Am J Forensic Med Pathol, 23(3), 268-271.

[28] Wiersema, J. M., \& Woody, A. (2016). The forensic anthropologist in the mass fatality context. Academic forensic pathology, 6(3), 455-462. https://doi.org/10.23907/2016.046

[29] Zvyagin, V. N., Galitskaya, O. I., \& Negasheva, M. A. (2012). Forensic investigation of body fragments during the mass receipt of corpses. Forensic-medical examination, 2(55), 410.

\section{ДОЦІЛЬНІСТЬ ЗАСТОСУВАННЯ КОМПЛЕКСНОГО ПІДХОДУ ПРИ ІДЕНТИФІКАЦІЇ ОСІБ, ЗНИКЛИХ БЕЗВІСТИ}

\section{Войченко В. В., Рощін Г. Г., Дядик О. О., Іркін І. В., Петрошак О. Ю., Костенко Є. Я., В'юн В. В., Зубко М. Д.}

Ідентифрікація зниклих безвісти в умовах збройного конфлікту та з масовими жертвами людей при надзвичайних ситуаціях має свої особливості і для підвищення точності та об'єктивності потребує комплексного підходу. Мета дослідження: обгрунтування доцільності комплексного підходу при ідентифрікації осіб, зниклих безвісти в умовах збройного конфрлікту та з масовими жертвами людей. У роботі були використані архівні матеріали судово-медичних експертиз комунального закладу "Дніпропетровське обласне бюро судово-медичної експертизи" стосовно загиблих осіб під час збройного конфрлікту і з масовими жертвами людей на сході України протягом 2014-2019 років. Методи дослідження: антропометричний, морфометричний, фоотографрічний, рентгенологічний, медико-криміналістичні методи, метод комп'ютерного моделювання, молекулярно-генетичний, статистичний. У статті викладено власний досвід підвищення об'єктивності та точності проведення ідентифрікації осіб, зниклих безвісти та визначення особливостей тілесних ушкоджень і травматичних чинників шляхом комплексного підходу з використанням антропометричного, морфометричного, фотографрічного, рентгенологічного, молекулярно-генетичного та медико-криміналістичних методів в умовах збройного конфрлікту $i$ з масовими жертвами людей. Проте наявність лише сучасного моргу та найновішого обладнання у відділі речових доказів бюро судово-медичної експертизи не є запорукою проведення успішної експертизи щодо ідентифрікації особи померлого. Як показує досвід різних країн світу у випадках масових природніх та техногенних катастрофр - ключовим елементом $\epsilon$ правильна і послідовна організація проведення досліджень. Досвід проведення ідентифрікаційних досліджень в Україні зниклих безвісти в умовах збройного конфрлікту та з масовими жертвами людей, свідчить про доцільність застосування комплексного підходу, який забезпечує підвищення об'єктивності та точності дослідження.

Ключові слова: ідентифрікація осіб, зниклі безвісти, тілесні ушкодження, травматичні чинники, комплексний підхід.

\section{ЦЕЛЕСООБРАЗНОСТЬ ИСПОЛЬЗОВАНИЯ КОМПЛЕКСНОГО ПОДХОДА ПРИ ИДЕНТИФИКАЦИИ БЕЗ ВЕСТИ ПРОПАВШИХ лиц}

Войченко В. В., Рощин Г. Г., Дядык О. О., Иркин И. В., Петрошак О. Ю., Костенко Е. Я., Вьюн В. В., Зубко М. Д.

Идентификация пропавших без вести в условиях вооруженного конфрликта и с массовыми жертвами людей при чрезвычайных ситуациях имеет свои особенности и для повышения точности и объективности требует комплексного подхода. Цель исследования: обоснование целесообразности комплексного подхода при идентификации лиц, пропавших без вести, в условиях вооруженного конфрликта и с массовыми жертвами людей. В работе были использованы архивные материалы судебно-медицинских экспертиз коммунального учреждения "Днепропетровское областное бюро судебно-медицинской экспертизы" относительно лиц, погибших во время вооруженного конфрликта и с массовыми жертвами людей на востоке Украины в 2014-2019 га. Методы исследования: антропометрический, морфометрический, фротографический, рентгенологический, медико-криминалистические методы, метод компьютерного моделирования, молекулярногенетический, статистический. В статье изложен отечественный опыт повышения объективности и точности проведения идентификации лиц, пропавших без вести и определение особенностей телесных повреждений и травматических фракторов путем комплексного подхода с использованием антропометрического, морфометрического, фотографического, рентгенологического, молекулярно-генетического и медико-криминалистических методов в условиях вооруженного конфлликта и с массовыми жертвами людей. Однако наличие только современного морга и новейшего оборудования в отделе вещественных доказательств бюро судебно-медицинской экспертизы не является залогом проведения успешной экспертизы по идентификации личности умершего. Как показывает опыт различных стран мира в случаях массовых природных и техногенных катастроф - ключевым элементом является правильная и последовательная организация проведения исследований. Опыт проведения идентификационных исследований в Украине лиц, пропавших без вести, в условиях вооруженного конфрликта и с массовыми жертвами людей, свидетельствует о целесообразности применения комплексного подхода, который обеспечивает повышение объективности и точности исследования. Ключевые слова: идентификация личности, без вести пропавшие, телесные повреждения, травматические факторы, комплексный подход. 